\title{
LEGAL NATURE OF DEPARTMENTAL REGULATIONS
}

\author{
Yuri G. Arzamasov 1 \\ National Research University Higher School of Economics \\ 3, Bolshoy Trekhsvyatitelskiy per., 123022, Moscow, Russia
}

The article is devoted to the establishment of the legal nature of departmental regulations. The main parameters and scope of rule-making competence of federal executive bodies are examined. Because of the heterogeneity of departmental normative acts, there is a need to develop a general multistage classification of departmental regulations, the creation of which will also help determine their legal nature.

Based on the analysis, a conclusion was made on the need for legislative regulation of the rule-making competence of federal executive bodies, as well as the procedure for implementing a departmental norm-setting process in the Russian Federation.

The question is debated whether the departmental normative acts are sources of law. It is concluded that departmental regulations perform the same functions as all other normative legal acts, that is, they create norms of law, modify and supplement existing norms, and in some cases cancel them. Consequently, these acts are sources (forms) of law.

The problem of the place, which departmental normative acts occupy in the system of subordinate normative acts, is being discussed. In conclusion, the author comes to the inference that departmental regulations possess all the features of by-laws.

It is noted that departmental regulations act as acts of developing norm-setting, since they carry out the functions of detailing and concretizing laws, acts of the President and the Government.

Key words: normative legal acts, subordinate legislation, departmental regulations, departmental norms of law, rule-making competence

\section{INTRODUCTION}

As of April 8, 2019, there are 56349 regulatory legal acts of federal executive authorities in the state register in the Russian Federation. On the Day of Russia, June 12, 2019, 55117 regulatory acts of federal executive bodies are already registered in the register. Such statistical data mainly show that there is a noticeable tendency, albeit insignificant, to reduce regulatory legal acts of federal executive authorities, i.e.

\footnotetext{
1 (C) Yuri G. Arzamasov, 2019.

This work is licensed under a Creative Commons Attribution 4.0 International License https://creativecommons.org/licenses/by/4.0
} 
departmental acts. If we compare the number of departmental acts with federal laws, we can see that today there are almost twice as much laws, their number is 118729 units.

Federal ministries and departments of the Russian Federation (federal services and federal agencies) exercising their functions, enshrined in the provisions of these bodies, and recently in administrative regulations, carry out various types of activities. At the same time, they can be expressed in various forms, both legal and nonlegal, in a variety of organizational measures.

The very legal nature of these acts has not been fully explored. There is no exhaustive answer to this question.

\section{FORMS OF IMPLEMENTATION OF FUNCTIONS OF FEDERAL MINISTRIES AND DEPARTMENTS}

The legal nature of departmental regulations is complex, which includes the concept of these regulations, their purpose, functions, forms of their implementation and, of course, their types. However, this list is not exhaustive either!

One of the first problems of defining the forms of implementing the functions of departmental rulemaking in the domestic theory of law was raised by Professor I.S. Samoschenko. He noted that the legal forms of exercising the functions of the ministries and departments of the USSR are: 1. law-making activity; 2. operational and executive activities; 3. law enforcement (Samoshchenko, 1956:85). Analyzing this classification, it should be clarified that law enforcement in general, except for the work of the judiciary, is the activity of subsystems of executive authorities. An example is the work of such federal ministries and departments of the Russian Federation as the Ministry of Internal Affairs, the Federal Security Services, etc. Thus, the main legal forms of exercising the functions of the executive branch are norm-setting and the application of legal norms.

\section{RULE-MAKING COMPETENCE OF FEDERAL EXECUTIVE AUTHORITIES}

To establish the legal nature of departmental normative acts, it is necessary to determine the main parameters and scope of the rule-making competence of federal executive bodies. To carry out the task, it is necessary to give answers to the following questions. Who gave the right to federal executive bodies to develop and adopt normative acts? What documents regulate this activity?

The regulation of this kind of legal activity of federal executive bodies, like rule-making, is carried out mainly by subordinate acts. Analysis of the regulatory material showed that there is a general normative act that defines the norm-setting competence of almost all federal executive bodies - the "Rules for the preparation of normative legal acts of federal executive bodies and their state registration", approved by the Government of the Russian Federation on August 13, 1997 No. 1009. Thus, the Art. 1 of the Rules states that normative legal acts are issued on the basis of and in 
compliance with federal laws, decrees and orders of the President of the Russian Federation, resolutions and orders of the Government of the Russian Federation, as well as on the initiative of federal executive bodies within their competence. These Rules also provide for a variety of forms of departmental regulations. According to the analyzed document, departmental normative acts are issued in the form of decisions, decrees, orders, rules, instructions and provisions ${ }^{2}$.

With the Decision dated 19 January 2005 by the Government of the Russian Federation, No. 30 "On the Standard Regulations for Interaction of Federal Executive Bodies" this list slightly increased, since the Standard Regulations of the federal executive bodies were approved. According to this document, each federal executive body was obliged to draft its own regulations by March 1, 2005 in accordance with the Standard Regulations. Also, federal executive authorities were required to develop administrative regulations for the performance of state functions, administrative regulations for the provision of public services and official regulations of civil servants of federal executive bodies.

As departmental normative acts are not homogeneous, both in form and by other criteria, this allows identifying the problem of the need to develop a general multi-stage classification of departmental regulations, the creation of which will also help determine their legal nature. However, considering this problem, in our opinion, requires a separate scientific discussion.

On 9 March 2004, Presidential Decree No. 314 "On the System and Structure of Federal Executive Bodies" was adopted and became a definite novel in the regulation of the normative competence of federal executive bodies. In this document, in subparagraph 3 (a), which describes the notion of the "federal ministry", it was noted that "the federal ministry is the federal executive body responsible for developing state policy and regulatory framework in established by the acts of the President of the Russian Federation and the Government of the Russian Federation sphere of activity". The right to exercise the functions of adopting normative legal acts by federal ministries is also enshrined in paragraph 3 (b) of the act under analysis, which states that, based on and in compliance with the Constitution of the Russian Federation, federal constitutional laws, federal laws, acts of the President of the Russian Federation and the Government of the Russian Federation, the federal ministry independently exercises legal regulation in the established field of activity, with the exception of issues, legal regulation of which, in accordance with the Constitution of the Russian Federation, federal constitutional laws, acts of the President of the Russian Federation and the Government of the Russian Federation are carried out exclusively by federal constitutional laws, federal laws, acts of the President of the Russian Federation and the Government of the Russian Federation. As for the rule-making competence of other elements of the system of federal executive bodies, that is, federal services

${ }^{2}$ Sobranie zakonodatel'stva Rossiiskoi Federatsii [Collection of legislation of the Russian Federation] (1997). (33), Art. 3895. 
and federal agencies, in paragraphs 4 and 5 of the decree it was noted that they have no right to exercise legal and regulatory regulation in the established sphere of activity, except cases, established by the decrees of the President of the Russian Federation $^{3}$. This state of affairs was primarily due to the fact that federal services and federal agencies are mainly under the jurisdiction of federal ministries. However, this rule did not last long, because on May 20, 2004 Presidential Decree No. 649 "Issues of the Structure of Federal Executive Bodies" was adopted, in paragraph 8 of which it states that "other federal executive bodies headed by the Government of the Russian Federation, perform the functions of adopting normative legal acts along with other functions stipulated by the Decree of the President of the Russian Federation of March 9, 2004 No. 314 "On the System and Structure of Federal Executive Bodies".

The analyzed normative act of the President practically equalized all federal bodies of executive power in the exercising of the rule-making competence, since it did not clearly state whether the federal services and federal agencies subordinated to the federal ministries, which are managed by the Government of the Russian Federation, can perform the functions of enacting normative acts. This fact suggests the need for not by-law, namely, legislative regulation of the rule-making competence of federal executive bodies, as well as the procedure for implementing the departmental law-making process in the Russian Federation in the form of the federal law "On rulemaking activity and regulatory acts of federal executive bodies".

Another problem of departmental rule-making is the adoption of regulatory legal acts to structural divisions and territorial bodies of federal executive bodies. Despite the fact that paragraph 2 of the Rules for the preparation of normative legal acts of federal executive bodies and their state registration, approved by the Decree of the Government of Russia of August 13, 1997 No. 1009 (as amended on 02.02.2019) prohibits the publication of normative legal acts to structural units and territorial bodies of federal executive bodies, in practice, in practically all subjects of the Russian Federation, territorial bodies of federal ministries adopt such acts. Moreover, the laws of many constituent entities of the Federation record the right to adopt regulatory legal acts to structural units and territorial bodies of federal executive bodies. An example is the Law of the City of Moscow of July 8, 2009 No. 25 "On Legal Acts of the City of Moscow" (as amended on April 29, 2019), in which in Article 4, which lists the elements of the system of legal acts in the city of Moscow, states that the system of legal acts of the city of Moscow includes "orders and instructions of the executive authorities of the city of Moscow - legal acts adopted by industry, functional and territorial executive authorities of the city of Moscow on matters related to the exercise of powers determined by the provisions on the relevant executive authorities of the city of Moscow, and signed by their leaders or other authorized officials of the organs.

${ }^{3}$ Rossiiskaya gazeta [Russian newspaper] (2004). $12^{\text {th }}$ of March. 
Indeed, without this regulation, territorial bodies of such federal ministries as the Ministry of Internal Affairs of Russia, the Ministry of the Russian Federation for Civil Defense, Emergencies and Disaster Relief, the Ministry of Natural Resources and Ecology of the Russian Federation, and a number of others will not be able to perform their functions.

In this regard, we believe that the rules prohibiting the issuance of regulatory legal acts to structural units and territorial bodies of federal executive bodies should be abolished, since these bodies simply cannot do without the adoption of necessary orders. It is important that these bodies deal only with intra-departmental, and not extra-departmental regulation.

\section{DEPARTMENTAL REGULATIONS AS SOURCES OF LAW}

The carried out analysis of the rule-making competence of the federal executive bodies does not answer the question: are departmental normative acts sources of law? Meanwhile, the solution of this theoretical problem contributes to the full disclosure of the legal nature of departmental regulations. However, in order to solve this problem, it is first of all necessary to determine the concept of "source of law", since in the general theory of law there are some basic approaches to understanding the source of law. The most common approach is often called "narrow" (formally legal), because in it the concept "form" and "source" of law coincide. According to this approach, sources of law are understood as those reservoirs, from which subjects of legal relations derive legal norms for solving legal problems.

Based on this approach, it should be noted, despite the fact that departmental regulatory legal acts are adopted, as a rule, on the basis of, or pursuant to federal laws and other acts of higher state authorities, they reinforce specific and detailed legal norms aimed at a certain regulation that allows you to call them the sources (forms) of law.

Further, to disclose the legal nature of departmental regulatory legal acts one should apply such a proven philosophical method of investigation as deduction, that is, first to consider the general concept of a normative act, then proceeding to specific features of departmental normative acts.

In the legal scientific literature regarding the understanding of a normative legal act, despite the fact that this concept has been repeatedly studied, there are different views.

S.V. Polenina and N.V. Silchenko considered the normative act as a certain "...system having its own structure, the elements of which are its features..." (Polenina, Sil'chenko, 1987:25). This statement, in our opinion, is not indisputable. Its disputability is manifested mainly in the fact that the system of law has traditionally been understood as a certain structure consisting directly of the norms of law, to be more precise, its elements, such as norms of law, legal institutions, industries and subbranches of law. According to Professor S.S. Alekseev, the main structure of law consists of such elements as branches, institutions and norms (Alekseev, 1975:23). 
However, there are other points of view on this problem in the theory of law and state. But in this particular case, it was better to speak not about the system, as the authors mentioned above, but about the legal structure, which, of course, should consist of interacting parts (elements).

V.A. Lysenko, I.S. Kramskoy and N.A. Ryazanova also pointed out in their article that "a normative legal act is a document expressed in writing, having an internal structure and clearly meeting the rules of legal technique" (Lysenko, Kramskoi, Ryazanova, 2015:207). In this definition, two interrelated aspects can be distinguished. Firstly, here we can see, although not explicitly, the connection between such three concepts of theory of law and state as "a source of law", "form of law" and "legal document", which is characteristic only of such legal documents as normative legal acts and normative treaties. The second aspect is the direct link, first of all, with legal technique. One can even say the result of its correct application. Here it should be noted that "legal technique" includes not only the totality or, to be more precise, the system of methods, rules and means aimed at preparation and adoption of laws and by-laws, but also acts of law application. As for the concept of "rule-making legal technique", it concerns only methods, rules and means aimed at the preparation and adoption of normative legal documents (acts and normative contracts), as well as technologies of legal monitoring in the process of norm-setting (Arzamasov, 2013:358).

Although, the term "rule-making legal technique" appeared long time ago, it was established in legal science after the publication of the monograph of the same name (Vlasenko, 2013).

Professor A.F. Shebanov wrote that a normative act is an act containing the norms of law (Shebanov, 1956:6). Such a definition would, in our view, be incomplete, since the functions of normative acts are different. In other words, the acts changing, supplementing, canceling other normative acts, as well as enacting other acts have not been taken into account. Thus, we can see that the functions of normative acts include:

- function or fixing norms of law, i.e. certain rules (standards) of behavior of subjects of law;

- function of making certain changes in normative legal acts;

- function of making additions to normative legal acts;

- function of cancellation of the whole normative legal acts or their separate parts (chapters, articles, paragraphs, etc.);

- function of approval or enactment of other normative legal acts. For example, in the Russian Federation all normative legal acts of federal executive authorities are approved by orders.

A certain theoretical and practical problem is the indication in the departmental normative act of which state body or official has adopted the relevant normative document. During the analysis of departmental documents, it was established that in a number of federal executive bodies departmental normative acts are issued on behalf of the "first person". An example is the Order of the Minister of Defense of the 
Russian Federation and the Minister of Education of the Russian Federation of May 3, 2001, No. 203/1936 "On approval of the Instruction on the organization of training of citizens of the Russian Federation for initial knowledge in the field of defense and their training in the basics of military service" 4 . In the Ministry of Defense, as analysis of normative material has shown, departmental regulations are always adopted on behalf of the Minister. This practice is also common in federal services.

The other example is the Order of the Russian Guard of 14.09.2018 No. 414 "On Amendments to the Order of the Federal Service of the National Guard of the Russian Federation of July 5, 2017 No. 196 "On Approval of the Procedure for Issuing Certificates of Veterans of Warfare in the Troops of the National Guard of the Russian Federation", which passed the official state registration procedure in the Ministry of Justice of the Russian Federation on September 20, 2018.

In most federal executive bodies, orders and other normative acts are not made on behalf of ministers and heads of departments, but on behalf of the authority. In this regard, it seems necessary to highlight the positive and negative points in the adoption of normative acts, both on behalf of heads of departments, and on behalf of public authorities. For example, if we proceed from the departmental principle of one-man management, then it should be noted that departmental regulations should be called orders of the minister, not ministries. This provision stems from the fact that the minister or other head of the federal executive authority, in accordance with his competence, at his own will, unless there is a direct indication of the law or another act, adopts a particular departmental normative document.

Speaking about the functions of normative acts, it should be noted that there are normative acts that carry out the functions of introducing additions and changes to existing normative acts ${ }^{5}$. Employee of the administrative department of the Institute of Legislation and Comparative Law under the Government of the Russian Federation N.A. Ignatyuk called the "addition", "concretization" and "detailing" of normative acts the ways of structural connection between normative acts. At the same time, she correctly pointed out their differences. In her opinion, with concretization, "the organizer-executor does not choose a specific version of the solution, because it is logically assumed to be the content of the main act, although it is not textually formulated". Detailing "leads to the formation of new rules of law, but it is needed in those cases when it is necessary to determine the procedure for the operation of the new rules of the main act, "to include" them in the system of current legislation" (Ignatjuk, 2003:154). In the general array of departmental normative acts, by analogy with other normative documents, there are also acts aimed at repealing the norms of law. In ad-

\footnotetext{
${ }^{4}$ Bjulleten' normativnyh aktov federal'nyh organov ispolnitel'noj vlasti [Bulletin of normative acts of federal executive bodies] (2001). (28), 3 .

${ }^{5}$ Order of the Ministry of Justice of the Russian Federation of June 27, 2001 No. 188 "On Amending the Order of the Ministry of Justice of the Russian Federation of November 12, 1998, No. 166 "On improving the work on the selection of specialized organizations for the sale of seized property" (2001). Bulletin of normative acts of federal executive bodies, (33), 18.
} 
dition, analogy can also be carried out as one normative act brings into play another, also the normative act can be canceled by another normative act ${ }^{6}$. However, there is one important condition: only the authority that passed it or the higher body of state power has the right to abolish the normative document, which in practice is extremely rare. Thus, for example, the President of the Russian Federation, although he has the right to cancel normative legal acts of the executive branch of power, he has never cancelled normative legal acts of federal executive authorities. As a rule, the President in such cases gives instructions to the Chairman of the Government of the Russian Federation or a specific federal minister.

In connection with what has been said, normative acts should be understood as legal acts that establish rules of law, modify or abolish the norms of law on the basis of which certain social relations arise. Despite the fact that in developing the concept of "normative act", it was not its signs that were taken as a basis, as it usually happens in the development of other legal terms, but directly the functions of the normative act, many lawyers shared this view ${ }^{7}$ (Mickevich, 1967:28). Such an approach, in our opinion, is fully objective and constructive. Nevertheless, this does not mean that from the traditional method of deducing a concept through its features, i.e. inductive method, the method "from private to general", should generally be abandoned.

To obtain a full-fledged result of the concept under study, one should not belittle the role of traditional methods of research, i.e. for a more comprehensive evaluation, it is also necessary to highlight the signs of normative acts. In our opinion, they can be of the following content:

1) normativity, i.e. contain certain rules of conduct - the rule of law, which allows you to refer normative acts to sources of law in a "narrow" sense;

2) repeated application - the effect of the prescriptions of the normative act is not one-time in nature and does not cease until its cancellation;

3) formalism, i.e. expressed in one form or another - regulations, instructions, etc.;

4) non-personification, i.e. apply to a broad, specifically vague circle of individuals;

5) regulate social relations, i.e. relations between different subjects, which for objective and subjective reasons directly or indirectly interact with each other.

The analysis of departmental regulations has shown that they possess all of the above characteristics and carry out all functions of normative acts. Moreover, de-

\footnotetext{
${ }^{6}$ Order of the Federal Service of Russia for Hydrometeorology and Environmental Monitoring of August 3, 2001, No. 116, "On the Recognition of the Order No. 14 of the Federal Service for Hydrometeorology of the Russian Federation dated 29 January 1996" (2001). Bulletin of Normative Acts of Federal Executive Bodies, (34), 127.

${ }^{7}$ See, e.g.: Pigolkin A.S. (1987). Juridicheskij jenciklopedicheskij slovar' [Legal encyclopedic dictionary]. Suharev A.Ja. (ed). Moscow, p. 254; Nikolaev O.V. (2002) Problema normativnosti aktov v rossijskom zakonodatel'stve [The problem of normative acts in the Russian legislation]. Jurist. (11), 12.
} 
partmental normative acts act as acts of developing norm-setting, since they carry out the functions of detailing and concretizing laws, acts of the President and the Government.

For a full analysis of departmental regulations, it is necessary to determine the place they occupy in the system of by-laws.

If we talk about the secondary legislation as a whole, it should be noted that this concept is a collective, because it includes normative acts that vary by different signs, such as: adoption body, legal power, object of regulation and other. Indeed, the whole range of supplementary legislation is very wide, it includes normative documents from the acts of the supreme bodies of state power (presidential decrees and resolutions of the Government) to the local, which set the house rules in any institution (organization).

Nevertheless, as shown by the analysis, the development of this concept in scientific works of recent years has been carried out repeatedly. In this connection, we should quote the most successful, in our opinion, definition given by Professor N.L. Granat: "A by-law normative act is a document issued in accordance with the law and is not contradictory, containing rules of law specifying, detailing and organizationally ensuring the operation of the law" (Granat, 1998:6-12).

It follows that the departmental regulations have all the features of subordinate legislation, and therefore they are not a source of law-formation and are not conducive to the formation of the rule of law as perform completely different functions (this was already mentioned above).

However, to determine the legal nature, it is necessary to carry out a comparative analysis of departmental normative acts with other legal acts.

It should be noted here that the federal executive bodies, that is, the federal ministries and departments, carrying out their activities, adopt a variety of legal (legal) acts. These are interpretive acts, i.e., acts of an official normative interpretation of departmental norms of law, which are often presented in the form of letters and explanations to the orders and instructions; also acts of application of law, which are used to solve current issues in government agencies, various institutions and organizations. Examples of such acts are various orders on personnel matters (on hiring, on dismissal, on incentives and punishments, on granting regular and additional leave, etc.). These orders have the following qualifying characteristics, which distinguish them from normative documents:

1) are of a personified nature, that is, a legal document specifies a certain range of subjects of legal relations, to which a specific prescription is addressed;

2) are authoritative in nature, because they are written with the help of an imperative (subordinate) method of legal regulation, and in this connection, they are mandatory for execution, whereas normative acts can fix normative recommendations;

3) a single-acting attitude, that is, having created a certain relationship on the basis of normative acts, they, as a rule, exhaust themselves and do not create new social relations. Thus, for these acts, one-time character is obvious. 
However, the direct implementation by ministries and departments of the functions and tasks assigned to them is carried out not only through acts of application of law, departmental normative acts, but also through so-called "mixed" legal acts.

In legal terms, the term "mixed act" was introduced in 1960 by C.A. Yampolskaya (1960:87), a year later on this topic published his article (Bratus', Samoshchenko, 1962:81). Later a similar opinion was expressed by A.V. Mickiewicz (1967:28).

Analysis of the regulatory acts of the federal executive authorities showed that most of these acts, as a rule, contain not only legal norms (rules of conduct), but one or several specific individual requirements. Individual orders are assigned to separate departments, offices, divisions and other units, as well as to specific officials of the ministry. Most often, individual requirements are contained in the last clause of the departmental order and impose duties on the enforcement of the rules of the order not only on any structural subdivision of the federal executive body, but also on a specific official. An exception is the special codified acts such as charters, instructions and administrative regulations, which are usually of a normative nature only.

However, in practice, sometimes the last paragraph of a purely legal act, such as an instruction, may also contain not only individual regulations, but also maps, charts, etc. In this regard, the normativity of such documents can be questioned. As the authors of the book "Theoretical Questions of Systematization of Soviet Legislation" note, "the presence in the act, along with the norms of law, of individual prescriptions does not deprive it of the properties of the source of law. It does it only by a purely normative act" ${ }^{\text {. }}$. Problems arise in a greater degree not in the theoretical plan, but in the implementation of the internal systematization of mixed departmental acts, since with such a systematization of the normative act, all the norms contained in the act are ordered, and when the mixed act is systematized, only normative regulations act as the object of systematization.

However, there are certain positive aspects in the adoption of mixed departmental regulations, since the consolidation in one act of the rules of law, individual and other prescriptions prevents the increase of an unnecessary number of legal prescriptions. In other words, the practice of adopting mixed acts in federal executive authorities serves as a deterrent tool in the fight against multiplicity in the departmental document flow.

Traditionally, in the Soviet, and later in the Russian legal science, researchers did not bypass their attention problems associated with both departmental rule-

\footnotetext{
${ }^{8}$ Teoreticheskie voprosy sistematizacii sovetskogo zakonodatel'stva [Theoretical questions of the systematization of Soviet legislation] (1962). Moscow, 81.
} 
making, and with its results - departmental regulations ${ }^{9}$. Nevertheless, departmental rules of law have been studied extremely rarely. In the meantime, departmental norms of law have their own characteristics, which distinguish them from other rules of law. Such norms, as a rule, regulate the relations within the ministry, which arise in the process of fulfillment by the ministries and departments of their functions. Nevertheless, departmental norms can regulate relations both with other authorities, that is, be of an interdepartmental nature, and with citizens, the result of which is the emergence of extra-departmental relations.

Some scholars studied the normative acts of a particular ministry or agency, while singling out both the general features of normative acts and the peculiarities inherent in the normative acts of a particular agency. For example, V.V. Chernikov, considering the normative acts of the internal affairs bodies, noted that in general terms, the normative legal acts of the internal affairs offices (NLA IAO) can be defined as written documents issued by authorized officials of the internal affairs offices, which establish, modify or abolish the rules of law. In addition, he singled out the following signs of normative legal acts of internal affairs offices:

- a document drawn up in accordance with the law;

- entitlement character;

- subordination (Chernikov, 1996:4).

This allows referring departmental regulations to the sources of law only in the "narrow" sense, that is, to such sources of law, when the concept of form and source of law are identical, that is, they coincide, when the source of law is understood as legal documents containing legal norms for resolving legal issues. This statement is based, first of all, on the fact that departmental normative acts perform the same functions as all other normative acts, that is, they create norms of law, modify and supplement existing norms, and in some cases cancel them. Consequently, these acts are sources of law only in the "narrow" sense.

Based on these theoretical and legal positions, we can safely refer departmental regulations to the instrumental elements of the legal regulation mechanism, along with such basic legal means as the rule of law, legal relations, legal facts, acts of the application of law. At the same time, these acts contribute to the further development of the regulation of the provisions of laws and other acts that have a greater legal force, since it is impossible to regulate the entire variety of social relations only by the norms of laws. In the departmental normative documents, in the main, the specification and detailing of the legislative provisions is carried out.

\footnotetext{
${ }^{9}$ See, e.g.: Shebanov A.F. (1965) Voprosy teorii normativnyh aktov v sovetskom prave: Dis. ... d-ra jurid. nauk. [Questions of the theory of normative acts in the Soviet law (PhD)]. Moscow; Nozdrachev A.F. (1968) Normativnye akty ministerstv i vedomstv SSSR: Dis. ... kand. jurid. nauk [Normative acts of ministries and departments of the USSR (PhD). Moscow; Nikolaeva M.N. (1975) Normativnye akty ministerstv i vedomstv SSSR [Normative acts of ministries and departments of the USSR]. Moscow; Zhevakin S.N. (1996) Vedomstvennye normativnye akty Rossijskoj Federacii: kratkij analiticheskij obzor [Departmental normative acts of the Russian Federation: a brief analytical review]. Gosudarstvo i pravo. (11).
} 
In addition, departmental regulatory acts provide organizational support for the operation of laws. Besides, these acts can also be referred to as an external form of uniting and streamlining the norms of law and, as a result, as effective means of influencing public relations. Combining the norms of law and the special provisions contained in their dispositions and, in general, general prohibitions and permissions, as well as legal obligations, the acts in question make technical elements in the mechanism of legal regulation of various social relations, contribute to its full-fledged work, which undoubtedly affects the establishment of the rule of law regime and legal order in the state. Nevertheless, departmental regulations act not only as a component of the operation of the general integrated mechanism of legal regulation, but also as constituent elements of certain departmental mechanisms of legal regulation in this or that sphere of public life (in the sphere of public order protection, registration of rights to immovable property and transactions with him, etc.)

In modern conditions of legal reform aimed at the creation of a new legal system, when the regulation of normative material is being regulated through consolidation, codification, with the introduction of modern computer types of accounting for normative acts, the relevance of the study of departmental regulations is beyond doubt. This is primarily determined by the fact that these acts form a special set of legal documents, the legal nature of which has been little studied, but which play an important role today in regulating relations in society.

In addition, despite the tendency to reduce the total number of departmental regulatory acts, there is an increase in the number of administrative regulations that contribute not only to the consolidation and implementation of state functions and public services, but also a means of preventing corruption. In this regard, there are serious scientific works investigating the legal nature of administrative regulations in modern Russia (Davydov, 2010:390; Korobkin, 2011:181).

\section{CONCLUSION}

Summarizing certain results, let us outline common features (signs) of departmental normative acts:

Firstly, departmental normative acts are one of the forms of implementing the competence of federal executive bodies.

Secondly, departmental normative acts are diverse, both in form and content of regulated relations.

Thirdly, this is a special legal force of departmental normative acts, that is, their subordinate nature.

Fourthly, departmental normative acts are the forms of Russian law defined by the Government of the Russian Federation, that is, sources of law in a "narrow" sense.

Fifthly, these acts can be assigned to both state authorities and citizens.

Sixthly, departmental regulations are a necessary element of the legal regulation mechanism. 
Thus, the selected features make it possible to derive the following concept. Departmental normative acts are sources of law that are the results of the rulemaking of competent persons of ministries and departments adopted on the basis of and in compliance with laws and other acts of supreme bodies of state power containing rules of law specifying, detailing and organizationally ensuring the operation of these acts.

In conclusion, it should be noted that to identify the legal nature of departmental regulations, it is not enough to list their characteristics and derive a definition, it is also necessary to determine the place and role of these legal documents in the system of normative acts, how they relate to other by-laws, what functions are carried out, what role in the mechanism of legal regulation. In addition, the creation of a general multistage classification of these acts is of great theoretical and empirical importance, but this is already the topic of another scientific article.

\section{REFERENCES / БИБЛИОГРАФИЧЕСКИЙ СПИСОК}

Alekseev, S.S. (1975) Struktura sovetskogo prava [Soviet law structure]. Moscow: Legal literature Publ. (in Russian).

Алексеев С.С. Структура советского права. М.: Издательство «Юридическая литература», 1975. $264 \mathrm{c}$.

Arzamasov, Yu.G. (2013) Teoriya i praktika vedomstvennogo normotvorchestva v Rossii [Theory and practice of departmental rulemaking in Russia]. Moscow. (in Russian).

Арзамасов Ю.Г. Теория и практика ведомственного нормотворчества в России: монография. М., 2013. 358 с.

Bratus', S.N., Samoshchenko I.S. (eds.) (1962) Teoreticheskie voprosy sistematizatsii sovetskogo zakonodatel'stva [Theoretical questions of the systematization of Soviet legislation]. Vsesoyuznyi institut yuridicheskikh nauk [All-Union Institute of Legal Sciences]. Moscow: Gosyurizdat Publ. (in Russian).

Теоретические вопросы систематизации советского законодательства / Всесоюзный институт юридических наук; под ред. С.Н. Братуся и И.С. Самощенко. М.: Госюриздат, 1962.575 с.

Chernikov, V.V. (1996) Normativnye akty organov vnutrennih del v sisteme pravovyh aktov upravlenija: Lekcija [Normative acts of internal affairs bodies in the system of legal acts of management: Lecture]. Moscow: The Ministry of Internal Affairs of Russia. (in Russian).

Черников B.B. Нормативные акты органов внутренних дел в системе правовых актов управления: лекция. М.: МЮИ МВД России, 1996. 24 с.

Davydov, K.V. (2010) Administrativnyye reglamenty federal'nykh organov ispolnitel'noy vlasti Rossiyskoy Federatsii: voprosy teorii [Administrative Regulations of the Federal Executive Authorities of the Russian Federation: Theoretical Issues]. Moscow: NOTA BENE. (in Russian).

Давыдов К.В. Административные регламенты федеральных органов исполнительной власти Российской Федерации: вопросы теории / под ред. д-ра юрид. наук, проф. Ю.Н. Старилова; монография. М.: NOTA BENE, 2010. 390 с.

Granat, N.L. (1998) Istochniki prava [Sources of law]. Jurist, 9, 6-12. (in Russian). Гранат Н.Л. Источники права // Юрист. 1998. № 9. С. 6-12.

Ignatjuk, N.A. (2003) Kompetencija federal'nyh ministerstv Rossijskoj Federacii [Competence of federal ministries of the Russian Federation]. Moscow. (in Russian). 
Игнатюк Н.А. Компетенция федеральных министерств Российской Федерации. М., 2003. $154 \mathrm{c}$.

Jampol'skaja, C.A. (1960) O pravovyh aktah Soveta narodnogo hozjajstva [On the legal acts of the Council of National Economy]. Sov. gosvo i pravo, 11. (in Russian).

Ямпольская Ц.А. О правовых актах Совета народного хозяйства // Сов. государство и право. 1960. № 11.87 с.

Korobkin, M. V. (2011) Administrativnyye reglamenty i problemy ikh realizatsii $v$ sisteme Ministerstva vnutrennikh del Rossiyskoy Federatsii [Administrative Regulations and Problems of Their Implementation in the System of the Ministry of Internal Affairs of the Russian Federation]: Dis. ... kand. yurid. nauk. Moscow. (in Russian).

Коробкин М.В. Административные регламенты и проблемы их реализации в системе Министерства внутренних дел Российской Федерации: дис. ... канд. юрид. наук. M., 2011. $181 \mathrm{c}$.

Lysenko, V.A., Kramskoi, I.S., Ryazanova, N.A. (2015) Particularities of Regulatory Legal Act as a Source of Russian Law. Bulletin of Economics, Law and Sociology, 4, 204-208. (in Russian).

Льсенко В.А., Крамской И.С., Рязанова Н.А. Особенности нормативно-правового акта как источника российского права // Вестник экономики, права и социологии. 2015. № 4. C. 204-208.

Mickevich, A.V. (1967) Akty vysshih organov Sovetskogo gosudarstva [Acts of the highest organs of the Soviet state]. Moscow: Legal literature Publ. (in Russian).

Мицкевич А.В. Акты высших органов Советского государства. М.: Юрид. лит. 1967. $175 \mathrm{c}$.

Polenina, S.V., Sil'chenko, N.V. (1987) Nauchnye osnovy tipologii normativno-pravovykh aktov v SSSR [Scientific basis of the typology of regulatory legal acts in the USSR]. Moscow: Nauka Publ. (in Russian).

Поленина С.В., Сильченко Н.В. Научные основы типологии нормативно-правовых актов в СССР. М.: Наука, 1987. 152 с.

Samoshchenko, I.S. (1953) O formah osushhestvlenija funkcij gosudarstva [On the forms of exercising the functions of the state]. Sov. gos-vo i pravo, 3. (in Russian).

Самощенко И.С. О формах осуществления функций государства // Сов. гос-во и право. 1956. № 3. С. 81-91.

Shatkov, G.I. (1962) O sootnoshenii soderzhanija i formy v aktah mestnyh organov gosudarstvennoj vlasti [On the relationship of content and form in the acts of local government authorities]. Pravovedenie, 1. 126-127. (in Russian).

Шатков Г.И. О соотношении содержания и формы в актах местных органов государственной власти // Правоведение. 1962. № 1. С. 126-127.

Shebanov, A.F. (1956) Normativnye akty Sovetskogo gosudarstva [Normative acts of the Soviet state]. Moscow: Moscow State University. (in Russian).

Шебанов А.Ф. Нормативные акты Советского государства. М.: МГУ, 1956. 39 с.

Vlasenko, N.A. (ed.) (2013) Normotvorcheskaya yuridicheskaya tekhnika [Rulemaking legal technique]. Moscow: Institute of Legislation and Comparative Law under the Government of the Russian Federation Publ. (in Russian).

Нормотворческая юридическая техника / под ред. Н.А. Власенко. М.: Институт законодательства и сравнительного правоведения при Правительстве Российской Федерации, 2013. 550 с. 
About author:

Yuri G. Arzamasov - Professor of the Faculty of Law of the Department of General and Intersectoral Legal Disciplines National Research University "Higher School of Economics"

ORCID ID: 0000-0002-4459-2920

e-mail: arzam.ruk@mail.ru

For citation:

Arzamasov, Yu.G. (2019) Legal nature of departmental regulations. RUDN Journal of Law. 23 (3), pp. 413-428. DOI: 10.22363/2313-2337-2019-23-3-413-428.

Article received May 23, 2019

Article accepted July 17, 2019

Научная статья

\title{
ПРАВОВАЯ ПРИРОДА ВЕДОМСТВЕННЫХ НОРМАТИВНЫХ ПРАВОВЫХ АКТОВ
}

\author{
Ю.Г. Арзамасов \\ Национальный исследовательский университет \\ «Высшая школа экономики» \\ 123022, Москва, Россия, Б. Трехсвятительский пер., 3
}

Данная статья посвящена установлению правовой природы ведомственных нормативных правовых актов. В ней рассматриваются основные параметры и объем нормотворческой компетенции федеральных органов исполнительной власти. В связи с неоднородностью ведомственных нормативных правовых актов возникает необходимость разработки общей поэтапной классификации ведомственных нормативных актов, создание которой также будет способствовать определению их правовой природы.

На основании проведенного анализа сделан вывод о необходимости законодательного регулирования нормотворческой компетенции федеральных органов исполнительной власти, а также порядка осуществления ведомственного нормотворческого процесса в Российской Федерации.

Обсуждается вопрос о том, являются ли ведомственные нормативные правовые акты источниками права в «узком» и «широком» значениях, приводятся точки зрения как отечественных, так и зарубежных авторов.

Сделан вывод, что ведомственные нормативные акты выполняют те же функции, что и другие нормативные акты, то есть создают нормы права, изменяют и дополняют существующие нормы, а в некоторых случаях отменяют их. Следовательно, эти акты являются источниками права только в «узком» смысле.

Более того, уделяется внимание вопросу о том, какое место ведомственные нормативные акты занимают в системе подзаконных нормативных актов. В заключение автор приходит к выводу, что ведомственные нормативные правовые акты обладают всеми особенностями подзаконных актов, а следовательно, не являются источниками правообразования и не способствуют формированию норм права.

Отмечается, что ведомственные регламенты действуют как акты нормотворчества, поскольку выполняют функции детализации и конкретизации законов, актов Президента и Правительства. 
Ключевые слова: нормативные правовые акты, подзаконные акты, ведомственные акты, ведомственные нормы права, нормотворческая компетенция

\section{Об авторе:}

Арзамасов Юрий Геннадьевич - доктор юридических наук, профессор, профессор Факультета права Департамента общих и межотраслевых юридических дисциплин Национального исследовательского университета «Высшая школа экономики»

ORCID ID: 0000-0002-4459-2920

e-mail: arzam.ruk@mail.ru

\section{Для цитирования:}

Арзамасов Ю.Г. Правовая природа ведомственных нормативных правовых актов // Вестник Российского университета дружбы народов. Серия: Юридические науки. 2019. T. 23 № 3. C. 413-428. DOI: 10.22363/2313-2337-2019-23-3-413-428.

Дата поступления в редакиию: 23 мая 2019 г. Дата принятия к печати:17 июля 2019 г. 